\title{
Response to: Coronavirus Disease 2019 (COVID-19) Learning Online: A Flipped Classroom Based on Micro-Learning Combined with Case-Based Learning in Undergraduate Medical Students [Letter]
}

\author{
Elizabeth Vacher \\ Paulina Bruessel (D) \\ UCL Medical School, London, WCIE \\ 6DE, UK
}

Correspondence: Elizabeth Vacher

Email Elizabeth.Vacher.14@ucl.ac.uk

\section{Dear editor}

We read with great interest the findings of Qian et al ${ }^{1}$ on how different online teaching styles may facilitate improved COVID 19 knowledge acquisition and commend the authors on their exploration of flipped classroom and case-based learning.

The COVID19 pandemic demanded a new approach to teaching be adopted and propelled forward the use of online teaching platforms and technology to make up for a lack of clinical teaching. As fifth-year medical students at a UK medical school, who have recently completed a year of COVID19 teaching, we would like to add insights into which teaching models were most effective.

The findings by Qian et al suggest that a flipped classroom model with microlearning and case-based learning may lead to greater knowledge gain and higher scores on knowledge tests compared to traditional teaching methods. There is already good evidence to support the use of flipped classrooms. Analysis of 28 comparative studies by Hew and Lo found flipped classroom models lead to a significant improvement in student learning compared to traditional classrooms ${ }^{2}$ and our experience echoes this.

However, in this study, case-based discussions were still teacher led. We suggest that greater improvement in learning may be achieved by having students present cases and prepare questions for their peers and teachers to respond to. This approach would facilitate consolidation of the cases students were exposed to throughout the pandemic in a constructive and safe classroom environment. A systematic review by Tai et al suggests that the use of peer assisted learning holds benefits for students, including development of communication and professional skills ${ }^{4}$. Therefore, future studies may benefit from incorporating the role of peer teaching into the flipped classroom model.

In addition, the study design chosen by Qian et al introduces three teaching models but does not allow the individual effect of each teaching style to be explored. Therefore, it is not possible to ascertain if the benefits in knowledge acquisition are due to the flipped classroom model, micro-learning or case-based learning. This is important because although case-based learning is enjoyed by students, Thistlethwaite et al found it to have inconclusive efficacy. ${ }^{3}$ 
Finally, in order to assess improvement in student knowledge a multiple-choice test paper may be of limited use. Online platforms could be better utilised to allow students to write long answers to set questions which are subsequently reviewed by teachers. This approach may negate the effects of memorisation and better delineate students' confidence in their knowledge.

\section{Disclosure}

The authors report no conflicts of interest in this communication.

\section{References}

1. Qian Q, Yan Y, Xue F, Lin J, Zhang F, Zhao J. Coronavirus disease 2019 (COVID-19) learning online: a flipped classroom based on micro-learning combined with case-based learning in undergraduate medical students. AMEP. 2021;28(12):835-842. doi:10.2147/AMEP.S294980

2. Hew KF, Lo CK. Flipped classroom improves student learning in health professions education: a meta-analysis. BMC Med Educ. 2018;18(1):38. doi:10.1186/s12909-018-1144-z

3. Thistlethwaite JE, Davies D, Ekeocha S, et al. The effectiveness of case-based learning in health professional education. A BEME systematic review: BEME guide no. 23. Med Teach. 2012;34(6):e421444. doi:10.3109/0142159X.2012.680939

4. Tai J, Molloy E, Haines T, Canny B. Same-level peer-assisted learning in medical clinical placements: a narrative systematic review. Med Educ. 2016;50(4):469-484. PMID: 26995485. doi:10.1111/medu.12898

Dove Medical Press encourages responsible, free and frank academic debate. The content of the Advances in Medical Education and Practice 'letters to the editor' section does not necessarily represent the views of Dove Medical Press, its officers, agents, employees, related entities or the Advances in Medical Education and Practice editors. While all reasonable steps have been taken to confirm the content of each letter, Dove Medical Press accepts no liability in respect of the content of any letter, nor is it responsible for the content and accuracy of any letter to the editor.

\section{Publish your work in this journal}

Advances in Medical Education and Practice is an international, peerreviewed, open access journal that aims to present and publish research on Medical Education covering medical, dental, nursing and allied health care professional education. The journal covers undergraduate education, postgraduate training and continuing medical education including emerging trends and innovative models linking education, research, and health care services. The manuscript management system is completely online and includes a very quick and fair peer-review system. Visit http://www.dovepress.com/testimonials.php to read real quotes from published authors. 